\title{
Testing of a force sensor used to measure the briquetting process parameters of lignocellulosic materials
}

\author{
Krzysztof Talaśka ${ }^{1, *}$, Dominik Wojtkowiak ${ }^{1}$, Ireneusz Malujda ${ }^{1}$ and Krzysztof Wałęsa ${ }^{1}$ \\ ${ }^{1}$ Chair of Basics of Machine Design, Poznan University of Technology, Poznan, 60-965, Poland
}

\begin{abstract}
The study presents a control and measurement system for the drive parameters of screw compactor machine with open working chamber for shredded materials. The study demonstrates the construction and working principle of the force sensor for measuring the axial force at the compacting screw. The calibration method for the measuring system was presented together with example measurement results for compaction of broken up rye straw, oat straw and hay. The study results were analyzed for feasibility of use for the compaction of materials with specific thermomechanical properties. The conclusion presents the possible forms of application of the established solution in mass production.
\end{abstract}

Keywords: worm/screw-based compaction machine, force sensor

\section{Introduction}

Manufacturing of solid fuels from broken down lignocellulosic materials has been steadily growing in popularity in the last years. This is caused by overproduction of materials suitable as fuel. Such overproduction is also observed in Poland since many years. Table 1 presents the balance of the total production compared to the utilization together with the forecast for the years 2010-2030.

Table 1. The balance of the total production and utilization of straw in the years 2010-2030 [1-8]

\begin{tabular}{|l|c|c|c|c|c|c|c|}
\cline { 2 - 8 } \multicolumn{1}{c|}{} & \multicolumn{9}{|c|}{ Year } \\
\cline { 2 - 8 } \multicolumn{1}{c|}{} & \multirow{2}{*}{2010} & 2011 & 2012 & 2013 & 2014 & \multicolumn{2}{c|}{ Forecast } \\
\cline { 5 - 9 } & & & & & & 2020 & 2030 \\
\hline Production [million tons] & 29.753 & 28.89 & 30.793 & 29.343 & 35.608 & 30.533 & 30.862 \\
\hline Utilization [million tons] & \multicolumn{7}{|c|}{} \\
\hline Mulch & 11.843 & 11.24 & 10.698 & 10.303 & 10.47 & 9.868 & 9.319 \\
\hline Fodder & 3.923 & 3.914 & 3.898 & 3.763 & 3.806 & 3.527 & 3.221 \\
\hline Green manure & 3 & 3 & 3 & 3 & 3 & 3 & 3 \\
\hline Bedding for mycelium & 1 & 1 & 1 & 1 & 1 & 1 & 1 \\
\hline Balance & 9.987 & 9.736 & 12.198 & 11.277 & 17.322 & 13.138 & 14.322 \\
\hline
\end{tabular}

\footnotetext{
* Corresponding author: krzysztof.talaska@put.poznan.pl

Reviewers: Grzegorz Domek, Andrzej Kołodziej
} 
Compaction of materials enables the change of their mechanical and usable properties as well as transport and storage conditions [8-15]. The manufacturing of solid fuels calls for the utilization of proper compaction technique. The most popular are piston, roller and screw based solutions. The utilization of any of the above methods depends on proper preconditioning of the material to be compacted. Pelletization utilizing roller technology calls for a finer breakdown of straw material. Whereas worm/screw-based compaction allows to compact cut straw with length from several to several dozen millimeters [8-15]. Fig. 1 shows the diagram of a compacting machine utilizing the screw technique with open forming sleeve.

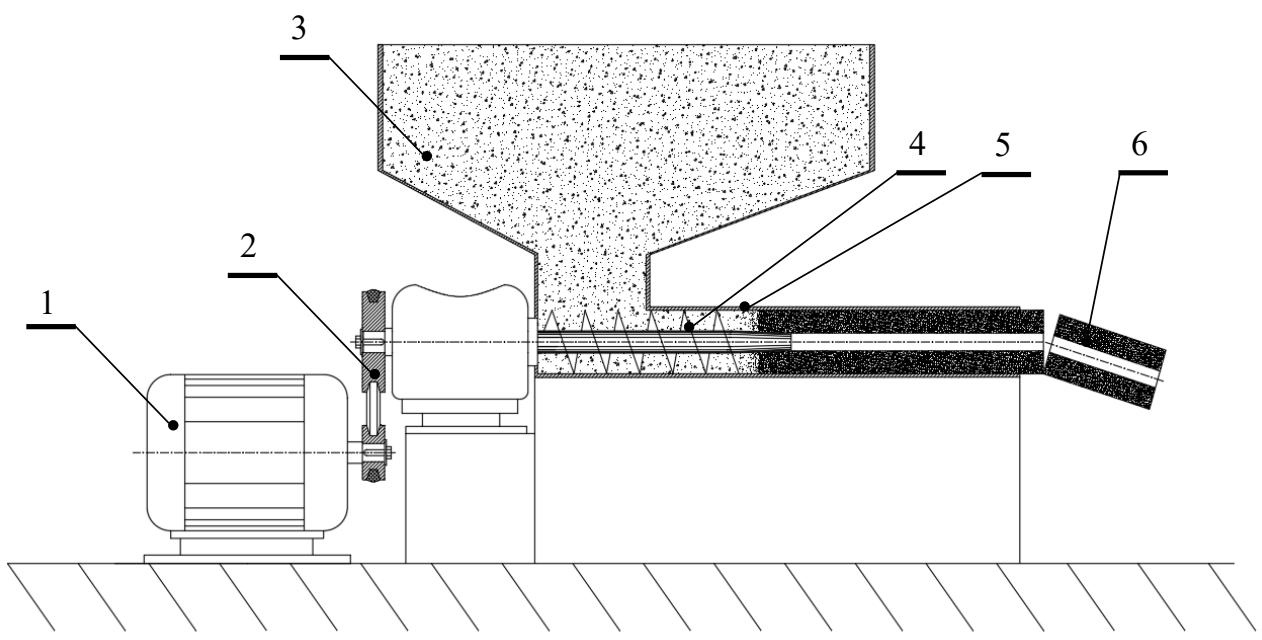

Fig. 1. Worm-based compaction machine with open forming sleeve used in the manufacturing of briquette from broken down lignocellulosic materials: 1 - drive motor, 2 - mechanical transmission, 3 - compacted material, 4 - worm, 5 - heated forming (compacting) sleeve, 6 - final geometric form of the agglomerate [8]

\section{Process parameters for the compaction of lignocellulosic materials utilizing compacting screw technique}

The working system of the machine utilizing the compacting screw consists of the two basic components: worm screw set in rotational motion via electrical drive together with the forming sleeve in which the worm performs the rotating motion. Fig. 2 presents the working system diagram of the machine utilizing compacting screw.

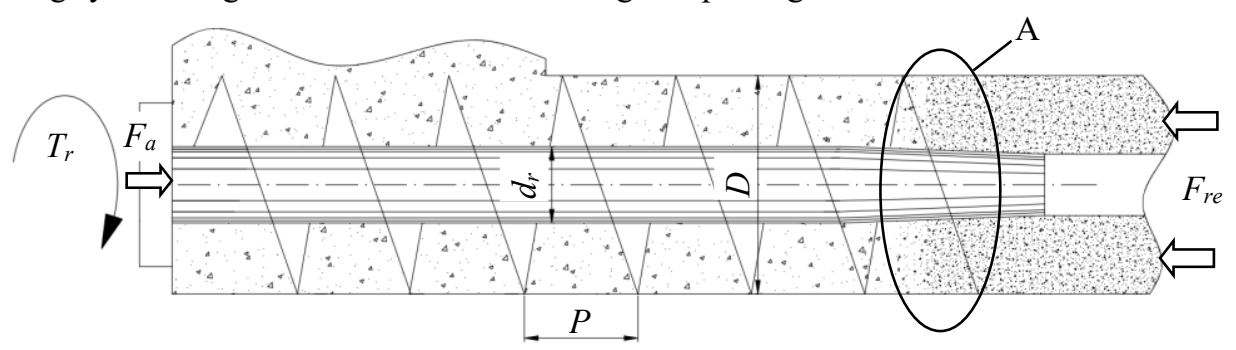

Fig. 2. Geometric properties of the working system of the compaction machine for broken down lignocellulosic materials (compacting screw technique): $D$ - diameter of the cylindrical part of the worm, $d_{r}-$ worm root diameter, $P$ - worm pitch, $F_{r e}$ - resistance force, $F_{a}-$ axial force, $T_{r}-$ torque, $\mathrm{A}$ - main compaction area of the material 
Analyzing the operating principle of such a working system, we can identify two basic functional parameters: the torque necessary to affect the rotating motion for compaction $T_{r}$, and resistance force $F_{a}$, which puts load on the worm during machine operation. The value of both parameters depend partially on the thermomechanical properties of the compacted materials. Therefore, during operation of the compacting screw mechanism, process temperature is another parameter to materially affect the entire process.

Identifying the torque and axial force values may be critical for machine control to facilitate efficient compaction process. Therefore, an attempt was made to suggest a construction solution for a specialized force gauge dedicated for this type of machine. The proposed solution is protected by a Polish patent no. 225645. Fig. 3 demonstrates the construction diagram of the force gauge.

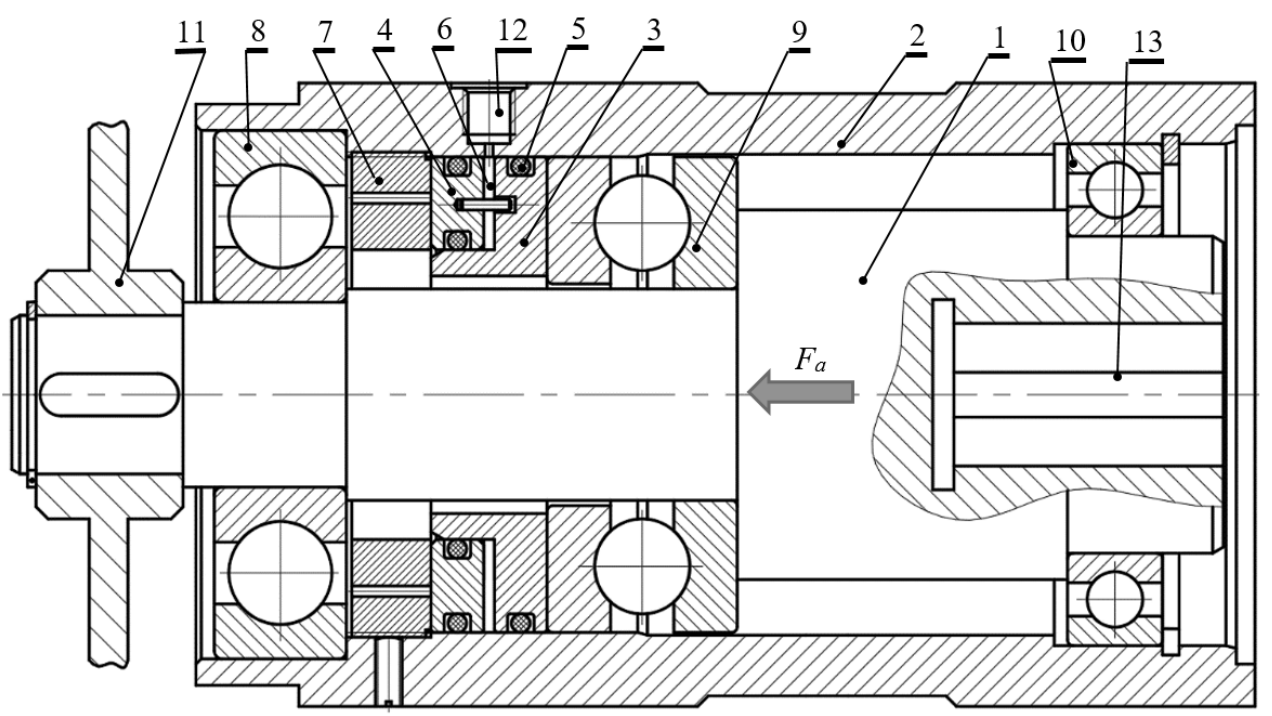

Fig. 3. Hydraulic rotational force gauge: 1 - shaft, 2 - body, 3 - force gauge body 1 , 4 - force gauge body 2, 5 - sealing ring, 6 - pressure chamber, 7 - threaded sleeve, $8,9,10$ - bearing, 11 - chain wheels, 12 - slot for pressure gauge, 13 - slot with inlet groove for the installation of worm pin, $F_{a}$ - axial force $[8,16]$

The operating principle of the presented force gauge is based on the direct measurement of the axial force based on the pressure change in the hydraulic chamber (between items no. 2, 3 and 4). After calibrating the force gauge using a durometer, it can be used to measure axial force for compacting selected materials. The calibration entails identifying the forcepressure characteristics allowing to use the pressure value within the hydraulic chamber to calculate the axial force accounting for resistances from construction.

\section{Methodology and scope of test measurements}

The examination was carried out on a compaction machine utilizing compaction worm screw. The compaction process was undertaken for oat straw, rye straw and hay (Fig. 4). The examination was carried out for three rotation speeds of the worm: 210,280 and 350 rpm. Figs. 5-7 present example results of the examination. Table 2 presents a breakdown of collected results of the axial force examination for the three materials at three rotation speeds of the worm. 


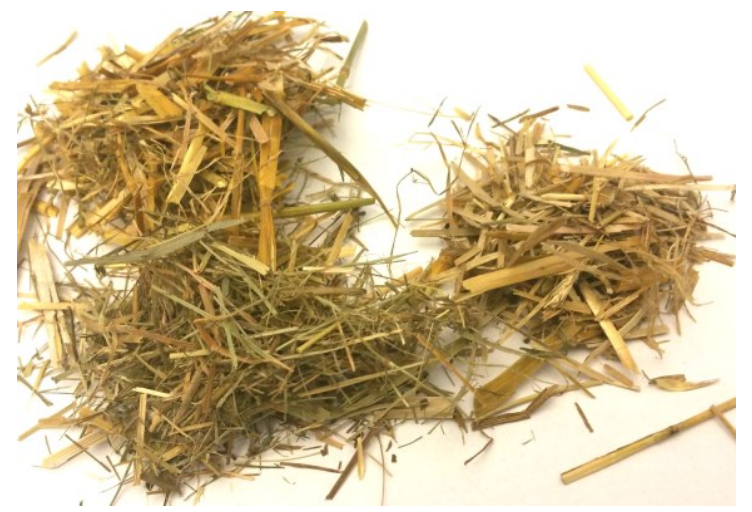

Fig. 4. Materials used for the examination: oat straw, rye straw, hay

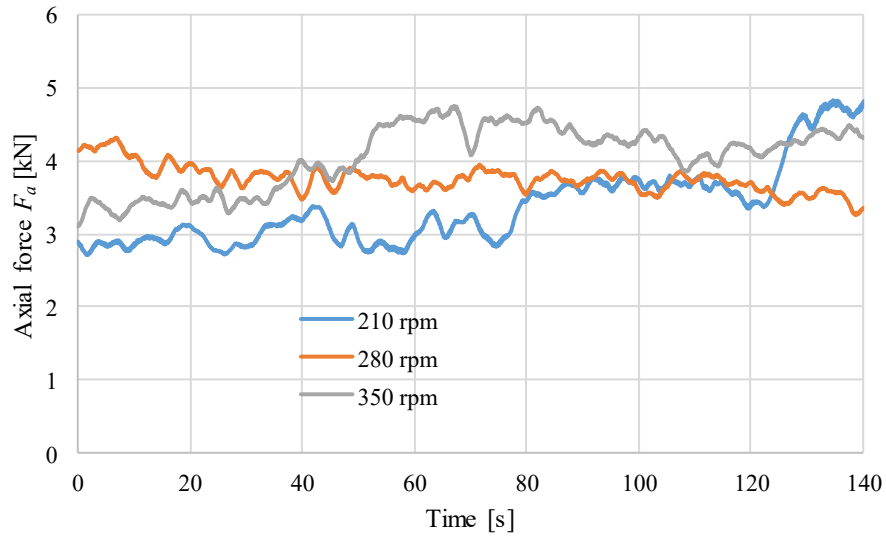

Fig. 5. The change of axial force $F_{a}$ as a function of time; rye straw

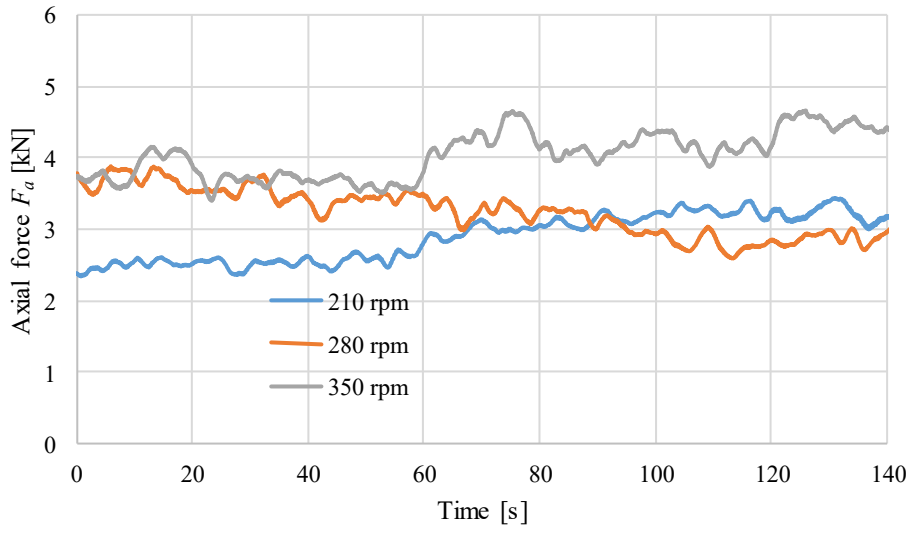

Fig. 6. The change of axial force $F_{a}$ as a function of time; oat straw 


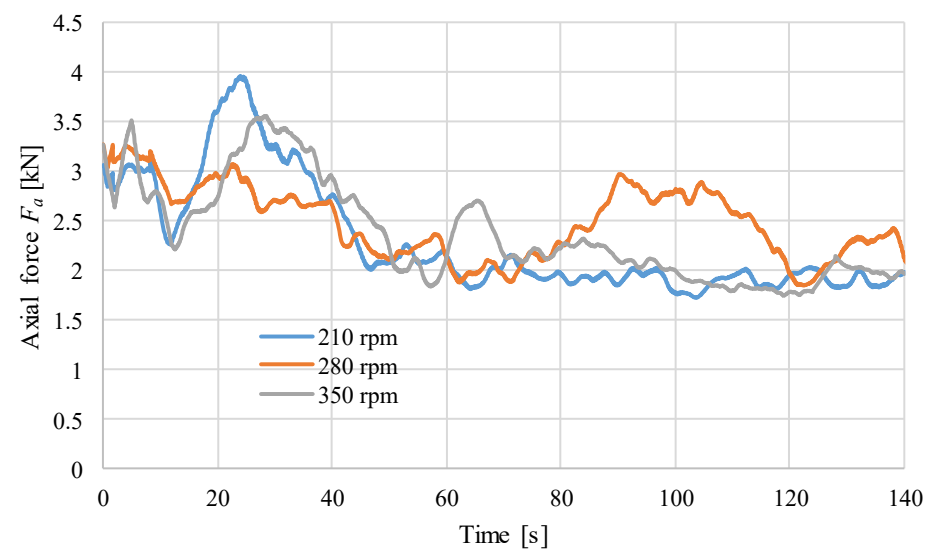

Fig. 7. The change of axial force $F_{a}$ as a function of time; hay

Table 2. Breakdown of results of the examination of axial force values $F_{a}$

\begin{tabular}{|l|c|c|c|}
\hline \multirow{2}{*}{ Material } & \multicolumn{3}{|c|}{ Axial force $F_{a}[\mathrm{kN}]$} \\
\cline { 2 - 4 } & $n_{s 1}$ & $n_{s 2}$ & $n_{s 3}$ \\
\hline Rye straw & $2.8-4.8$ & $3.2-4.2$ & $3.1-4.8$ \\
\hline Oat straw & $2.3-3.4$ & $2.7-3.9$ & $3.4-4.7$ \\
\hline Hay & $1.7-4.0$ & $1.8-3.3$ & $1.8-3.6$ \\
\hline
\end{tabular}

\section{Conclusion}

The proposed hydraulic force gauge intended for use in the compacting machine utilizing worm screw technique fulfills its purpose successfully. The variability of the compaction process of the broken down lignocellulosic materials prevent designing dedicated working systems for specific materials. It is therefore much more advantageous to utilize dedicated measurement systems allowing to monitor selected parameters during machine operation. This may be utilized to control the machine utilizing the known value of axial force load on the auger. Analyzing the results of the study, we can conclude that even within a single type of material, the variability of the axial force value is considerable. The value ranges of axial force for different materials overlap. This confirms the thesis regarding the suitability of designing dedicated, specialized measuring systems allowing constant control of the selected parameter during machine operation.

\section{References}

1. GUS: Characteristics of farms in 2013 (in Polish), Warszawa (2014)

2. GUS: Production of agricultural and horticultural crops in 2014 (in Polish), Warszawa (2015)

3. GUS: Land and sown area use in 2014 (in Polish), Warszawa (2015)

4. GUS: Livestock in 2014 (in Polish), Warszawa (2015)

5. A. Faber, J. Kuś, Alternative directions of production of Polish agriculture (in Polish), Pamiętnik Puławski, 132, pp. 59-73 (2003)

6. Cz. Maćkowiak, Straw as a fertilizer on a farm without inventory (in Polish), Wieś Jutra, 5, pp. 46-48 (1998) 
7. A. Madej, Straw balance in Poland in 2010-2014 and forecast by 2030 (in Polish), Stowarzyszenie Ekonomistów Rolnictwa i Agrobiznesu, Roczniki Naukowe, t. XVIII, z. 1, pp. 163-168 (2016)

8. K. Talaśka, Study of research and modelling of compaction processes of powder and shredded materials (in Polish), Wydawnictwo Politechniki Poznańskiej, Poznań (2018)

9. K. Talaśka, I. Malujda, D. Wilczyński, Agglomeration of natural fibrous materials in perpetual screw technique - a challenge for designer, Procedia Engineering, 136, pp. 63-69 (2016).

10. D. Wilczyński, K. Talaśka, I. Malujda, R. Długi, The Study of Mechanical Properties of Natural Polymers in the Compacting Process, Procedia Engineering, 177, pp. 411418 (2017)

11. I. Malujda, D. Wilczyński, Mechanical Properties Investigation of Natural Polymers, Procedia Engineering, 136, pp. 263-268 (2016)

12. D. Wilczyński, K. Talaśka, I. Malujda, P. Jankowiak, Experimental research on biomass cutting process, MATEC Web of Conferences, 157, Article Number 07016 (2018)

13. J. Górecki, I. Malujda, K. Talaśka, M. Kukla, P. Tarkowski, Influence of the compression length on the ultimate stress in the process of mechanical agglomeration of dry ice, Procedia Engineering, 177, pp. 363-368 (2017)

14. J. Górecki, I. Malujda, K. Talaśka, P. Tarkowski, M. Kukla, Influence of the value of limit densification stress on the quality of the pellets during the agglomeration process of $\mathrm{CO}_{2}$, Procedia Engineering, 136, pp. 269-274 (2016)

15. J. Górecki, I. Malujda, K. Talaśka, D. Wojtkowiak, Dry ice compaction in piston extrusion process, Acta mechanica et automatica, 11, pp. 313-316 (2017)

16. J. Płotkowiak, J. Adamiec, M. Dudziak, I. Malujda, K. Talaśka, Hydrauliczny siłomierz obrotowy, Polish patent no. 225645, Warszawa (2017) 